\title{
The Pro's And Con's Of Arbitration: A Study Of International Arbitration With Perspective Of Indonesian And Korean Law
}

\author{
Akhmad Al-Farouqi Sastrowiyono \\ Postgraduate Program Facultyof Law UniversitasIslam Indonesia \\ Jln. Cik Di Tiro No. 1 Yogyakarta 55223 \\ arukiruki18@gmail.com
}

\begin{abstract}
Essentially, everyone wants their business torun well and smoothly, but dispute in the international business dealings can always happen, as internationalization generates new risks. Compared to disputes between domestic entities, international business dispute shave extra problem sincluding various jurisdictions, diverse legal systems and tradition, different procedures and oftenin volving more than one language. Arbitration is one of the way to settle the dispute but there are always pros and consaboutit. This will discuss about the advantages and disadvantages of arbitration from the point of view of both Indonesian and Korean Law, by using the normative-juridical method. In which the results conclude that there are important practical differences between litigation and arbitration from which the disputing parties can choose which settling way would they prefer according to the avantages and disadvantages.
\end{abstract}

Keywords: Indonesian law; international arbitration; Korean law; pro's and con's

\begin{abstract}
Abstrak
Pada dasarnya, semua orang ingin bisnis mereka berjalan dengan baik dan lancar, tetapi perselisihan dalam transaksi bisnis internasional selalu dapat terjadi, karena internasionalisasi menimbulkan risiko baru. Dibandingkan dengan perselisihan antara entitas domestik, perselisihan bisnis internasional memiliki masalah tambahan termasuk berbagai yurisdiksi, beragam sistem dan tradisi hukum, prosedur yang berbeda dan seringkali melibatkan lebih dari satu bahasa. Arbitrase adalah salah satu cara untuk menyelesaikan perselisihan tetapi selalu ada pro dan kontra tentang hal itu. Artikel ini akan membahas tentang kelebihan dan kekurangan arbitrase dari sudut pandang Hukum Indonesia dan Korea, dengan menggunakan metode normatif-yuridis. Hasil penelitian menyimpulkan bahwa ada perbedaan praktis yang penting antara litigasi dan arbitrase yang mana pihak yang berselisih dapat memilih cara penyelesaian yang mereka inginkan sesuai dengan keuntungan dan kerugiannya.
\end{abstract}

Kata-kata Kunci: Arbitrase internasional; hukum Indonesia; hukum Korea; pro dankontra 


\section{Background}

With the rapid growth of international trade, businesses - including small and medium-sized enterprises (SMEs) - are increasingly exposed to new partners, countries, cultures, legal systems and trade practices. These new opportunities can bring new risks, especially if vital information and market intelligence is missing. ${ }^{1}$

Business relationships can always lead to disagreements, problems and disputes. This is why effective dispute prevention and dispute resolution are an important component of risk management for any company. In an international context, there are additional difficultiesinvolving different jurisdictions, legal traditions, laws and procedures and sometimes the use of many Languages. ${ }^{2}$ Basically, everyone wants their business to run well and smoothly. However, not always everything can go with what is expected. The existence of unwanted things sometimes happens, such as a dispute arising from misunderstanding in understanding the existing agreement. And this should be addressed and resolved so as not to drag on. Basically, dispute settlement can be done through 2 process. The oldest dispute resolution process through the litigation process in the courts, then the process of dispute resolution through cooperation outside the court. The non-litigation dispute resolution form ADR (Alternative Dispute Resolution), ADR may be in the form of arbitration.

During the drafting of a dispute resolution clause, the first decision to be made by the contractual parties is whether to have disputes resolved by arbitration or litigation. Contractual parties usually agree in advance on what will happen if a dispute arises. There are two options generally open to the parties: (1) litigation before the courts of a specific country; and (2) international arbitration.

${ }^{1}$ International Trade Centre, Settling Business Disputes: Arbitrationand Alternative Dispute Resolution, 2nd ed., International Trade Centre, Geneva, 2016. 


\section{Problem Formulation}

What are theadvantages and disadvantages of arbitration in the settlement of international business disputes based on the perspective of Indonesian and Korean Law?

\section{Research Objectives}

The purpose of this study is to analyze and understand the Pros and Cons of Arbitration as an effective dispute prevention and dispute resolution for the company based on the perspective of Indonesian and Korean Law.

\section{Research Method}

The research approach used is a normative juridical approach. The material used is secondary data including books, journals, dictionary, and applicable laws.

\section{Discussion and Results}

\section{Defining Arbitration}

Accordingto Black's Law Dictionary, arbitration is anarrangement for taking an abiding by the judgement of selected persons in some disputed matter, instead of carrying it to establish tribunals of justice, and is intended to avoid the formalities, the delay, the expense and vexation of ordinary litigation. ${ }^{3}$

According to Indonesian Law No. 30 of 1999 on Arbitration and Alternative Dispute Resolution, article 1 paragraph (1): “Arbitration is a way to settle a civil dispute outside a general court based on arbitration written agreements by the disputing parties"4

According to Korean Arbitration Act as Amended by Act No. 14176, May 29, 2016, Article 3 paragraph (1-3) The term "arbitration"means a procedure to resolve a dispute over a property right or a dispute over a non-propertyright, which can besettled by compromise between parties, by an a ward of arbitrators under anagreement between parties, not by judgment of a court by the agreement

3Black's Law Dictionary.

${ }^{4}$ Indonesian Law No.30 of 1999 on Arbitration and Alternative Dispute Resolution. 
between the parties to settle by arbitration, all or some disputes which have already occurred or mightoccur in the future with regard to defined legal relationships, whet her contractualor not with help sofsingle arbitratoror a panel of arbitrators who conduct arbitral proceeding sand make arbitra law ards. 5

Business conflicts or disputes can be resolved not only through litigation or through courts, but may also be resolved through non-litigation way finding. Alternative dispute resolution as a dispute settlement is a series of processes aimed at resolving disputes between the parties. Initially the settlement of disputes is seen as an alternative to the judge's decision, to a decision on legal dispute indicating which techniques can be used to resolve disputes without formal decisions, obtained through arbitration than courts. ADR mechanisms usually involve a fair (impartial) arbitrator who acts as a third party or a neutral party. ${ }^{6}$ It is intended to prevent the settlement of disputes through arbitration to be long-drawn-out. In contrast to the judicial process of the country where to its decision the parties may still submit an appeal and cassation, then in the process of dispute settlement through arbitration is not open the appeal of appeal cassation or reconsideration. ${ }^{7}$

Currently, arbitration is most commonly used for commercial dispute resolution, especially in the context of international commercial transaction. It is also used in some countries to resolve other types of disputes, such as labor disputes, consumer disputes, and dispute settlements between states and between investors in certain states. ${ }^{8}$

In the business world order fulfillment of consumer needs, sometimes happen things that are not desirable such as misunderstanding in understanding the contents of a contract, the unfulfilled rights of labor by business actors etcetera. As international conflicts arise, so does the use of arbitration to overcome them. There are basically two types of arbitration, ad hocand institutional. Institutional arbitration is one entrusted to one of the major arbitration bodies to be dealt with,

${ }^{5}$ Korean Arbitration Act as Amended by Act No. 14176, May 29, 2016.

'I Made Widnyana, Alternatif Penyelesaian Sengketa (ADR), Fikahati Aneska, Jakarta, 2009, pg. 11.

${ }^{7}$ Indonesian Law No.30 of 1999 on Arbitrationand Alternative Dispute Resolution.

8“International Dispute Resolution Overview", https://gnso.icann.org/en/drafts/intl-dispute-resolutionoverview-june-2007.pdf, accessed on 8 April 2019. 
while an ad hoc is conducted independently without such an organization and in accordance with the rules prescribed by the parties and its lawyers. ${ }^{9}$

In every hearing of the Arbitrator Assembly shall first strive for mediation between the parties. The parties are given the flexibility of time to mediate either inside or outside the court. Nevertheless, the mediation process remains under the supervision of the Arbitrator Assembly in order not to become protracted without the certainty of settlement.

The choice of caucus (separate meetings) is often done by the Arbitrator Assembly to find out a clearer picture of the problem from the parties. In this process, the parties have the discretion to discuss with the arbitral assembly, let alone the arbitral panel has read the entire lawsuit (petition) and answers. On the other hand, this arbitrator is the expert in their field, so the discussion to the technical issues to lead to the settlement can go well. Although not all cases can be resolved through mediation.

\section{Indonesian and Korean Arbitration}

Arbitration in Indonesia is governed by Law No. 30 of 1999 on Arbitration and Alternative Dispute Resolution ("Arbitration Law"). The Arbitration Law defines arbitration as a method of settling a civil dispute outside the general court, based on an arbitration agreement made in writing by the disputing parties. The district courts do not have jurisdiction to hear disputes between parties that are bound by an arbitration agreement. ${ }^{10}$ The Arbitration Law prescri best he arbitration process in Indonesia, such as the appointmen to far bitrators by the parties, confidentiality of the proceeding sand, final and binding nature of the arbitral award. ${ }^{11}$

Before the Arbitration Act come to anenforce, the provision scon cerning arbitration shall begoverned in Articles 615 to 651 ofthe Indonesian Civil Procedural Rules (Rv). In addition, in the elucidation of Article 3 Paragraph (1) of Law No.14 of

${ }^{9}$ Ibid.

${ }^{10}$ Indonesian Law No.30 of 1999 on Arbitrationand Alternative Dispute Resolution, Article 3.

${ }^{11}$ Timur Sukirno and Ferry Aritonang, Hadiputranto Hadinoto \& Partners, "Arbitration procedure sandpractice in Indonesia: overview", https://uk.practicallaw.thomsonreuters.com/9-520-8397, accessed on 8 April 2019. 
1970 on the Principles of Judicial Power states that the settlement of cases outside the Court in the meaning of peace or through referees (arbitration) is still allowed.

In Indonesia, there is an institution that oversees the arbitration named BANI. BANI is the dispute resolution institution through arbitration mechanism. Dispute resolution forum is much in demand by business people because it feels more efficient and effective than the courts. Arbitration is the method of settling a civil dispute outside the general court based on an arbitration agreement made in writing by the parties to the dispute. Advocates are in creasingly pushing clients to settle disputes through arbitration. ${ }^{12}$

While Korea signed the New York Convention on the Recognition and Enforcement of Foreign Arbitral Awards (the NY Convention) on 8 February 1973, and it entered into force on 9 May 1973. Korea made two declarations, namely, that it will apply the NY Convention to the recognition and enforcement of awards made only in the territory of another contracting state, andthat it will apply the NY Convention only to differences arising out of legal relationships, whether contractual or not, which are considered commercial under Korean law. ${ }^{13}$

The Korean Arbitration Act (the Act) was first enacted in 1966, but was entirely revised as of 31 December 1999 to substantially adopt the UNCITRAL Model Law (the Model Law). In May 2016, the Korean legislature passed extensive amendments to the Act that took effect on 30 November 2016 (the 2016 Amendments to the Act), and these amendments incorporate many key features of the 2006 UNCITRAL Model Law (the 2006 Model Law). The Act applies to all arbitral proceedings seated in Korea. In addition, Articles 9, 10, 37 and 39 of the Act will apply even if an arbitral proceeding is seated elsewhere. The Korean Commercial Arbitration Board (KCAB) istheonly officially recognized arbitral institution in Korea. KCAB acts as an appointing authority for $\mathrm{KCAB}$ arbitrations and may act as an appointing authority in non-KCAB arbitrations seated in Korea. ${ }^{14}$

12“Perjanjian Arbitrasen dan Pasal 1266 KUHPerdata", http://www.hukumonline. com/berita/baca/lt5915a2f04745b/perjanjian-arbitrase-dan-pasal-1266-kuh-perdata, accessed on 8 April 2019.

13http://globalarbitrationreview.com/jurisdiction/1000194/korea, accessed on 8 April 2019.

${ }^{14}$ Ibid. 
Arbitration remains a major dispute resolution mechanism in international trade. Arbitration is effective for large transactions. Other methods, such as mediation, are more personalized to the needs and reality of SMEs. The parties may elect, and sometimes shall, bring their case to court or national administrative authority. However, for most contracts involving parties from various countries, businesses may feel disadvantaged if their disputes are trialed before a court of others party, in the other party's language and in accordance with the procedural rules of their counterparts. ${ }^{15}$

Neutrality and flexibility are the basic reasons why alternative dispute resolutions (ADRs) such as mediation have been developed, with the support and cooperation of the courts. In deciding whether to agree on arbitration, there are also pros and cons to consider such as: time constraints, the need for special knowledge, confidentiality, and international enforcement.

\section{Pro's}

As explained before there are several reasons for choosing arbitration instead of litigation are because of these factors such as neutrality, expertise, confidentiality, procedural flexibility, abilityto choose the language and place of arbitration, Maintaining the relation between parties, the finality of the award and enforceability.

\section{a. Neutrality}

In addition to their selection of neutrals of appropriate nationality, parties are able to choose such important elements as the applicable law, language and venue of the arbitration. This allows them to ensure that no party enjoys a home court advantage. ${ }^{16}$ The courts in any country have their own formalities, their own rules, their own procedures while the courts in one party's jurisdiction are inevitably "foreign" to any party that is not from that jurisdiction. Giving jurisdiction to the courts of a neutral country does not improve the situation: after all, the courts will be "foreign" to both parties. For most contracts involving

\footnotetext{
${ }^{15}$ International Trade Centre, Loc. Cit.

16"What is Arbitration", http://www.wipo.int/amc/en/arbitration/what-is-arb.html, accessed on 8 April
} 2019. 
parties from various countries, businesses may feel disadvantaged if their disputes are trialed before a court of others, in the other party's language and in accordance with the procedural rules of their counterpart country. In arbitration a dispute is normally dealt with in a neutral forum rather than in the courts of one party's own country, each party participates in the selection of the tribunal, which may consist of a sole arbitrator or of three arbitrators. ${ }^{17}$ Each party ordinarily selects one arbitrator. Those two arbitrators (or an outside institution) agree on the selection of the third arbitrator.

\section{b. Expertise of the arbitrators}

The arbitrators can be selected for their specific expertise. This is important in disputes involving highly technical matters for which specific technical knowledge, qualifications and experience are required in complex cases, the arbitrator may be joined by an expert (such as an accountant or psychologist), so you can rest easy that your case is handled properly even if your arbitrator does not have expertise in a certain area. ${ }^{18}$

In additiontothe above, for arbitrations seated in Korea, parties should be aware that the Act provides them with the right to appeal decisions of the tribunal to the court of competent jurisdiction with respect to challenges to an arbitrator. ${ }^{19}$

Arbitrators have expertiseand competence in the field of business which became the subject matter in the case. In Article 12 paragraph (1) sub-paragraph e of the Indonesian Arbitration Act is determined one of the conditions to be appointed as an arbitrator, having experience and active power in his field for at least 15 years. ${ }^{20}$

\section{c. Confidentiality}

Its confidential nature makes arbitration seen as an alternative solution in accordance with the needs of the business world. This is because arbitration is held in private. Unlike open dispute resolution methods in public courts,

${ }^{17}$ Houthoff Buruma, International Commercial Arbitration: An Introduction, 2013, pg. 9-10.

18“Arbitration Pro's and Con's”, https://lisagelman.com/mediation/arbitration-pros-and-cons/, accessed on 8 April 2019.

${ }^{19}$ Korean Arbitration Law, Articl 14.

${ }^{20}$ Indonesian Arbitration and Alternative Dispute Resolution Law, Article 12 paragraph (1) sub-paragraph e. 
arbitration is attended only by interested parties or, in other words, the parties to the dispute.

The privacy and confidentiality of arbitral proceedings is very attractive to companies and institutions involved in international transactions that do not wish the disputes and the details of the transactions to become public. No one else is present, no reporter can blow up the news. The correspondence is also all secret. ${ }^{21}$

Arbitration proceedings are carriedout in a sessi on closed to the public, to ensure the confidentiality of the arbitration processas in Article 27 ofLaw No. 30 of 1999 on Arbitration and Alternative Dispute Resolution Law. Generally, the Arbitration Law guarantees the confidentiality of the dispute. ${ }^{22}$ However, the Arbitration Law does not expressly state that the final arbitration award is confidential. In addition, the Indonesian National Board of Arbitration Rules (BANI) specifically provides that (except to the extent required by law) all proceedings must be closed to the public. All matters related to the arbitration are to be kept in strict confidence among the parties, the arbitrators and BANI, except as otherwise agreed by all parties to the dispute. These matters include: documents; reports or notes of sessions; the testimony of witnesses; and awards. ${ }^{23}$

\section{d. Flexibility}

Arbitration procedure as set forth in Chapter IV Law no. 30 of 1999 on Arbitration and Alternative Dispute Resolution, in its application can be more flexible by taking into account the agreement of the parties. Where possible the designated arbitrator reconciles the interests of the parties to the dispute. The procedure is not too formalistic, although keeping in mind the important guidelines that have been determined and agreedupon.

Another advantage to arbitration lies in the fact that the issues will not be addressed in a formal courtroom, under the watchful eye of an intimidating judge, which can be rather frightening. The parties can file pleadings, witnesses

\footnotetext{
21 "Making Ngetrend ini 5 Kelebihan Penyelesaian Sengketa Melalui Arbitrase", http://www.hukumonline.com/berita/baca/lt58a6bf5208d32/makin-ngetrend--ini-5-kelebihanpenyelesaiansengketa-melalui-arbitrase, accessed on 8 April 2019.

${ }^{22}$ Indonesian Law No. 30 of 1999 on Arbitration and Alternative Dispute Resolution Law, Article 27.

${ }^{23}$ TimurSukirno, Loc. Cit.
} 
can be examined and cross-examined, and the rules of evidence are honored. On the other hand, if you prefer a more informal approach, your arbitration can take place with all parties seated at the same table, in an informal setting, it can be done in any country, any place, it can be done informally just like in Hotel of Jeju island or Meeting room in Bali. This flexibility is very attractive for many parties, especially those who are opposed to the formalities of the courtroom. ${ }^{24}$

\section{e. Freedom of choice in the procedure, language and place}

The parties can decide to conduct the arbitration in the language of their choice. This language will be used not only in the oral hearings, but also in the briefs and supporting documents that must be submitted. Parties Instruct that every document submitted to them must be accompanied with a translation using a language determined by the arbitrators as in Article 35 of the Indonesian Arbitration Law. ${ }^{25}$

The parties have the flexibility to adapt the procedure to suit the situation. They are not bound by national or local rules of civil procedure and the often slow and expensive litigation that results. Rather than having to submit to the jurisdiction of a court in the country of the other party, the parties have the freedom to agree to a neutral or more convenient place (or both) for the conduct of the arbitration. ${ }^{26}$

\section{f. Finality of the Award}

According to Indonesian Law, Article 60 of Law No. 30 of 1999, "Arbitralawardis final and has permanent legal power and binds the parties." A party can request revocation of an arbitral award by petition if: 27

After the awardis issued, a party finds that the letters or documents submitted in the proceedings are false, or they are declared to be false. After the award is issued, it is discovered that the other party concealed decisive documents. The award is issued as a result of fraud by one of the parties. The petition must be filed in writing within 30 days of the date of delivery and

${ }^{24}$ Lisa Gelman, “Arbitration Pro’s and Con's”, https://lisagelman.com/mediation/arbitration-pros-andcons/, accessed on 8 April 2019.

${ }^{25}$ Indonesian Law No. 30 of 1999 on Arbitration andAlternative Dispute Resolution, Article 35.

${ }^{26}$ Houthoff Buruma, Op. Cit.pg. 12.

${ }^{27}$ Indonesian Law No. 30 of 1999 on Arbitrationand Alternative Dispute Resolution, Article 70. 
registration of the arbitration award with the clerk of the respective district court. The petition must be filed with the chairman of the respective district court who must make a decision within 30 days of receiving the petition. If the petition is granted, the chairman of the respective district court must determine the consequences of revocation for the whole or part of the arbitration a ward.

While according to Korean Law in Article 13 of the Act provides that an arbitrator may be challenged if circumstances exist that are likely to give rise to justifiable doubts as to the arbitrator's impartiality or independence, or if the arbitrator does not possess qualifications agreed on by the parties. Under article 14 of the Act, the parties are free to agree on a procedure for challenging an arbitrator. Failing such an agreement, the party challenging an arbitrator shall send a written statement of the grounds for challenge to the arbitral tribunal within 15 days of becoming aware of (i) the constitution of the arbitral tribunal or (ii) the grounds for challenge. Unless the challenged arbitrator withdraws, or the other party agrees to the challenge, the arbitral tribunal shall decide on the challenge. If the arbitral tribunal rejects the challenge, the challenging party may, within 30 days of being notified of the decision, request that the court decide on the challenge. The court's decision is final and not subject to appeal. ${ }^{28}$

Subject to certain provisions of national law or a specific agreement between the parties, an arbitral award is final: it will not, as the case with court judgments, be the first step on an expensive ladder of appeals.

\section{g. Maintaining the relation between parties}

Though not always a win-win solution, at least in the case of a company that has a dispute with a government-owned company, a verdict can be made that provides legal certainty when dispute arises because of different interpretations.

The business relationship between the client and the counterpart, or counterpart, remains well established and the contract of cooperation continues. Once there is a verdict, the existing contracts between the parties continue, as the intent is not to terminate the existing contract.

\footnotetext{
${ }^{28}$ Korean Arbitration Act, Article 13-14.
} 


\section{h. Enforceability}

The judgment of a local court is enforceable only in that country while an arbitration award rendered in the Indonesia or Korea is enforceable in over 140 countries. This is pursuant to international treaties, including the New York Convention of 1958, to which the Indonesia and Korea are a party. Korea has also ratified the Convention on the Settlement of Investment Disputes between States and Nationals of Other States (the Washington Convention). Korea signed the Washington Convention on 21 February 1967, and it entered into force on 23 March 1967.29

\section{i. Time and Costs}

Arbitration proceedings are relatively short, compared to final and binding court judgments. The Arbitration Law provides that the examination of a case must not take longer than 180 days starting from when the arbitration tribunal is formed as of the appointment of the arbitrator (in the event of one arbitrator) or formation of the arbitrary panel (in the event of three arbitrators). While a court process could take multiple years. Even though the initial arbitrator costs and filing fees are higher than Court fees, due to the rapid arbitration process legal service fees can be held under control. Moreover, the arbitrator can decide in its decision to allocate all or part of the costs to the losing party. More time and cost effective. In contrast, civil proceedings require a large amount of time and will give rise to significant legal expenses.

\section{j. Reputation}

Indonesian Courts in Indonesia face in general a negative reputation caused by corruption and an insufficient sophistication of courts. Therefore, institutions such as BANI are generally preferable to the Indonesian Courts for overseas investors. ${ }^{30}$ Such as KCAB for Korea.

\section{Con's}

\section{a. Not suited for multi-party disputes.}

Arbitration is conducted most easily when there are only two parties involved-one as the claimant and the other as the respondent. An arbitral

${ }^{29}$ Doo-Sik Kim, Jae Min Jeon, Seung Min Lee and Arie Eernisse, “Commercial Arbitration 2017”, Global Arbitration Review.

30"Arbitration BANI vs Courts Indonesia", https://www.indonesia-investments.com/business/businesscolumns/arbitration-bani-vs-courts-inindonesia/item5409?, accessed on 8 April 2019. 
tribunal has no power to order someone who is not a party to the arbitration agreement into arbitration against their will. ${ }^{31}$

\section{b. Possible delays}

Arbitration parties are increasingly complaining about delays, particularly at the beginning and end of the arbitration. At the beginning, the complaint is that it takes too long to constitute an arbitral tribunal and, thus, to commence with the arbitration. At the end of the arbitration, the complaint is that some arbitral tribunals take too much time to make their award. ${ }^{32}$

\section{c. Execution}

The disadvantage of using arbitration arises when it comes to the execution of arbitration awards. Arbitration awards, whether domestic or international, must be registered with the courts in Indonesia and require the involvement of the court to issue an exequatur and writ of execution. Awards can also be challenged by the opposing party on the grounds of decency or public order. Therefore, it may take longer to effectively execute the award. ${ }^{33}$

In Indonesia, Article 60 of the Arbitration Law states that the arbitral award is final and has permanent legal force binding on the parties. In theory, after an arbitration ruling there is no other remedy that can be filed by the losing party and the victorious live execution. In fact, the execution of an arbitral award is not as easy as that. Article 61 of the Arbitration Law provides that execution shall becarried out under the orders of the Chairman of the District Court if any party does not implement the arbitral award voluntarily. It means, the District Court is not allowed to examine the principal matter again. Their job only allow sorrefuses execution.

For international arbitration awards, execution can only be executed by the Central Jakarta District Court after the award is filed (enlisted) in the Registrar. If the court refuses to execute, the reasons are only limits specified in article 66 point

\footnotetext{
${ }^{31}$ Houthoff Buruma, Op.Cit.

${ }^{32}$ Ibid

${ }^{33}$ Timur Sukirno, Loc. Cit.
} 
$a, b, c$ of the Arbitration Law in the event that the international arbitration award does not include the scope of the trade and is contrary to public order.

Limited power smight be the answer. In general, arbitrators have less power than a judge in a court of law. Not a new story if the execution, neither the verdict of arbitration, nor verdict of civil court verdict is only a victory on paper only. Once execution is requested, various procedures and constraints will been countered.

In thecaseof Olimo, the owner of a spare parts shop in dispute about the deposit to the NV King Kong bus company for 33 years has not been completed. Three execution orders were postponed due to conflicting Supreme Court decisions. Thus, the arbitral award without execution is also meaning less.

Beside the prosand cons, there are several cases related to the arbitration which enlist the number of people to not choose the arbitration because of the cases.

One of the example is a case about arbitration clause where the main point of the arbitration is an arbitration clause. The arbitration clause will determine whether a dispute can be settled by arbitration, where it is settled, which law is used, and so on. The arbitration clause may stand alone or be separate from its principal agreement.

BANI (Badan Arbitrase Nasional Indonesia) provides the standard of arbitration clause as follows: "All disputes arising from this contract shall be binding and be finally settled under the administrative and procedural Rules of Arbitration of Badan Arbitrase Nasional Indonesia (BANI) by arbitrators appointed in accordance with saidrules".

"Any dispute, controversyor claim arising out of or relating to this contract, or the breach, termination or invalidity thereof, shall be settled by arbitration in accordance with the UNCITRAL Arbitration Rules as at present in force."

One of the cases referred is a dispute between Bankers Trust (BT) vs. PT Jakarta International Hotel Development (JIHD). Disputes between BT vs. JIHD has actually has come to the verdict. The London International Arbitration Court has issued a verdict which essentially states that JIHD has defaulted and has been pledged. JIHD was also sentenced to pay compensation to BT. Even though 
according to the lawyer, The London International Arbitration Court has ruled out a dispute in which there is no arbitration clause.

There is also another case about Separate Lawsuit: The Indonesian Arbitration Act itself expressly determines that the District Court is not authorized to adjudicate disputes of parties that have been bound by arbitration agreements (art. 3). There is a dispute between Roche International and PT Tempo Indonesia filed by civil lawsuit in the District Court, although there is an arbitration clause in the agreement. According to the Head of Central Jakarta District Court cannot order the judge in the Central Jakarta District Court to refuse to examine cases where the material contained an arbitration clause.

Under article 5 of the Indonesian Arbitration Law, disputes that can be resolved through arbitration are merely disputes in the field of trade and on rights which, by law and legislation, are fully controlled by the parties to the dispute. According to Indonesian commercial court, the arbitration clause is something absolute. Therefore, the Commercial Court must declare that it is not authorized to examine the dispute in which there is an arbitration clause in it.

Article $616 \mathrm{Rv}$ states among other things concerning grants, divorces, disputes of one's status anddisputes governed by statutory provisions cannot be submitted to arbitration. This means that bank ruptcy case scan not be filed for arbitration due to bank ruptcy specially regulated in Law No. 4 of 1998 on Bankruptcy.

\section{Conclusion}

Basically, everyone wants their business to run well and smoothly. However, not always everything can go with what is expected, dispute might happen so dispute settlement can be done through two process, litigation or nonlitigation such as Arbitration. The process of resolving business disputes through non-litigation channels provides justice for the parties to the dispute, since the final result is based on an agreement of the parties who both take the path that is beneficial to the parties, with the result made by the parties that is win-win solution make the parties feel satisfied with the settlement of disputes through 
non-litigation channels especially for business actors or businessmen, if there is a dispute can be resolved quickly and cheaply so not waste much time, thoughts, energy and cost. In the course of arbitration this certainly affects the judiciary and business disputes in every country including Indonesia and Korea because there are important practical differences between litigation and arbitration, and at the level of the shorter ADR process. There are lots of advantages that we can get by the arbitration tribunals but, there are some disadvantages too and the parties may choose one of the way to settle the dispute by considering both of the way as explained before.

\section{References}

\section{Book}

Buruma, Houthoff, International Commercial Arbitration: An Introduction, 2013.

International Trade Centre, Settling Business Disputes: Arbitrationand Alternative Dispute Resolution, 2nd Ed., International Trade Centre, Geneva, 2016.

Widnyana, I Made, Alternatif Penyelesaian Sengketa (ADR), Fikahati Aneska, Jakarta, 2009.

\section{Journal}

Kim, Doo-Sik, Jae Min Jeon, Seung Min Lee and Arie Eernisse, "Commercial Arbitration 2017", Global Arbitration Review.

\section{Laws}

Indonesian Law No. 30 of 1999 on Arbitrationand Alternative Dispute Resolution Korean Arbitration Act as Amended by Act No. 14176, May 29, 2016.

\section{Dictionary}

Black's Law Dictionary

\section{Internet}

"Arbitration BANI vs. Courts Indonesia", https://www.indonesiainvestments.com/business/business-columns/arbitration-bani-vs.courtsin-indonesia/item5409, accessed on 8 April 2019.

http://globalarbitrationreview.com/jurisdiction/1000194/korea, accessed on 8 April 2019.

"International Dispute Resolution Overview", https:/ /gnso.icann.org/en/drafts/ intl-dispute-resolution-overview-june-2007.pdf, accessed on 8 April 2019.

Lisa Gelman, “Arbitration Pro's and Con's", https:/ /lisagelman.com/mediation/ arbitration-pros-and-cons/, accessed on 8 April 2019. 
"Makin Ngetrend Ini 5 Kelebihan penyelesaian Sengketa Melalui Arbitrase", http:/ / www.hukumonline.com/berita/baca/lt58a6bf5208d32/makinngetrend--ini-5-kelebihanpenyelesaian-sengketa-melalui-arbitrase, accessed on 8 April 2019.

Sukirno, Timur, Ferry Aritonang, Hadiputranto Hadinoto \& Partners, "Arbitration procedures and practice in Indonesia: Overview", https://uk.practicallaw.thomsonreuters.com/9-520-8397, accessed on 8 April 2019.

"Perjanjian Arbitrase dan Pasal 1266 KUHPerdata", http://www.hukumonline. com/berita/baca/lt5915a2f04745b/perjanjian-arbitrase-dan-pasal1266kuh-perdata, accessd on 8 April 2019.

"What is Abritration", http://www.wipo.int/amc/en/arbitration/what-isarb.html, accessed on 8 April 2019. 